\title{
PERAN BANK SAMPAH SEBAGAI TEMPAT KEGIATAN UNTUK MENINGKATKAN PEREKONOMIAN MASYARAKAT
}

\author{
Aris Eddy Sarwono ${ }^{1}$, Sunarti ${ }^{2}$ \\ Universitas Slamet Riyadi Surakarta \\ Email: aris_sarnur@yahoo.co.id njarkasi@gmail.com
}

\begin{abstract}
ABSTRAK
Kegiatan pengabdian ini memiliki tujuan dan target untuk meningkatkan produktifitas dan kualitas penanganan sampah terutama sampah non organik. Kegiatan pengabdian ini dilakukan pada kelompok bank sampah mawar yang ada di perumahan Joho di Kabupaten Sukoharjo. dengan melakukan kegiatan pelatihan dan pendampingan. Bentuk pelatihan yang diberikan kepada mitra terutama mengelola sampah yang berasal dari bahan plastik (non organic) menjadi handycraf sehingga memliki nilai ekonomis. Hasil kegiatan pengabdian ini dari kegiatan pendampingan dalam hal manajemen keuangan adalah tertatanya pengelolaan bank sampah dan meningkatnya produktivitas hasil kerajinan berupa handycraf berbahan sampah non organik.

Kata Kunci : Bank Sampah, Non Organik, Produktivitas, Nilai Ekonomis
\end{abstract}

\section{PENDAHULUAN}

Dalam Undang Undang Nomor 18 Tahun 2008 tentang Pengelolaan Sampah, bahwa masyarakat perluu melakukan cara pandang yang berbeda bagaimana mengelola sampah dan memperlakukannya agar pengelolaan tersebut dapat dilakukan dengan baik. Dalam peraturan tersebut secara implisit menjelaskan bahwa cara pandang masyarakat pada sampah seharusnya tidak lagi memandang sampah sebagai hasil buangan yang tidak berguna, akan tetapi sampah seharusnya dipandang sebagai sesuatu yang mempunyai nilai guna dan manfaat.

Pengelolaan sampah juga di atur dalam Undang-undang No 81 Tahun 2012, pengelolaan sampah rumah tangga dan sampah sejenis sampah rumah tangga, maka praktek mengolah dan memanfaatkan sampah harus menjadi langkah nyata dalam mengelola sampah. Dalam hal ini, masyarakat harus meninggalkan model memperlakukan sampah yang hanya membuang sampah dan perlu sekarang untuk membiasakan masyarakat memilah, memilih, dan menghargai sampah sekaligus mengembangkan ekonomi kerakyatan melalui pengembangan bank sampah.

Menurut Jumar (2014), cara pemilahan sampah rumah tangga yang termasuk kategori sampah organik dapat dijadikan kompos sedangkan sampah rumah tangga non argonik ditabungkan ke bank sampah untuk didaur ulang kembali dan dapat dijadikan bahan yang bernilai ekonomis dan menambah pendapatan bagi masyarakat. Pada dasarnya bank sampah dapat digambarkan dalam konsep pengumpulan sampah kering dan dipilah serta memiliki manajemen layaknya perbankan, tetapi yang ditabung bukan uang melainkan sampah. Warga yang menabung juga disebut nasabah dan memiliki buku tabungan serta dapat meminjam uang yang nantinya dikembalikan dengan sampah seharga uang yang dipinjam. Sampah yang ditabung akan ditimbang dan dihargai dengan sejumlah uang, kemudian akan dijual di pabrik yang sudah bekerja sama dengan bank sampah

Dalam kegiatan pengabdian ini, mitra yang digunakan dalam adalah kelompok masyarakat yang tergabung dalam bank sampah mawar di Joho Kabupaten Sukoharjo. Kegiatan bank bank sampah tersebut tergolong memiliki prospek yang baik, hal ini bisa terlihat jumlah anggota dari tahun ke tahun selalu meningkat. Pada awal pendirian jumlah anggota kedua kelompok tidak lebih dari 10 orang, akan tetapi pada tahun 2019, jumlah anggota sudah lebih dari 30 orang. Mekanisme untuk kegiatan menabung sampah dari anggota dilakukan seminggu dua kali yaitu pada hari sabtu dan minggu. 

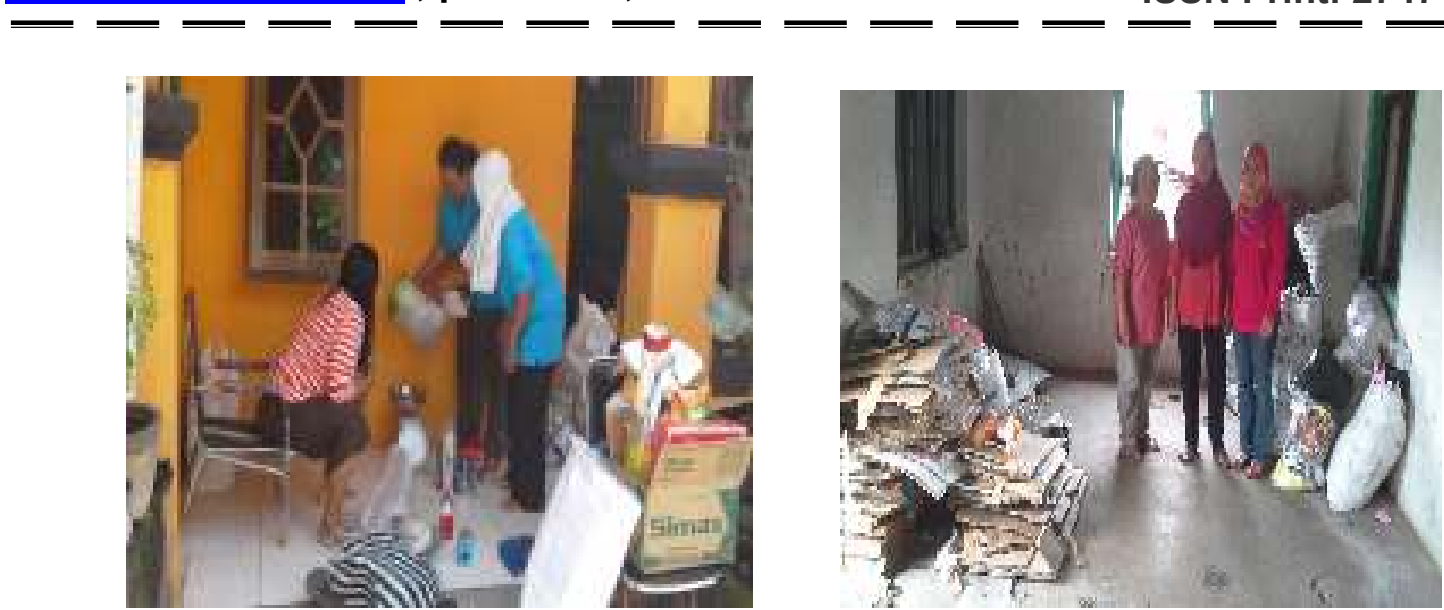

Gambar 1a dan 1b : Kondisi obyek pengabdian

Kondisi lingkungan aktifitas bank sampah utamanya pada penaganan sampah-sampah belum menggambarkan kodisi yang baik. Selain itu beberapa sampah non organik juga dilakukan untuk membuat beraneka macam barang sebagai (memanfaatkan barang bekas), namun peralatan yang digunakan juga belum baik. Kondisi pengelolaan manajemen, keuangan dan administrasi masih menggunakan pola manajemen dengan pencatatan yang bersifat sangat sederhana, demikian pula dalam mencatat penerimaan dari nasabah bank sampah juga belum memadahi, termasuk laporan pertanggungjawaban pengurus bank sampah kepada nasabah juga belum dilakukan dengan baik. Fasilitas yang dimiliki oleh bank sampah tersebut adalah masih sangat sederhana kondisi gudang penampungan sampah dan fisiknya.

Kegiatan ini secara garis besar memiliki tujuan untuk pemanfaatan sampah non organik dan penataan manajemen bank sampah. Untuk tujuan pertama yaitu pemanfaatan sampah non organik, jenis sampah non organik yang diterima seperti kardus, botol minuman baik plastik maupun kaca, kain-kain dapat dimanfaatkan untuk membuat aneka ragam produk yang dapat dijual. Untuk tujuan yang kedua yaitu pendampingana manajemen, kondisi bank sampah yang memiliki prospektif untuk dikembangkan secara lebih baik, bank sampah perlu melakukan pengelolaan secara maksimal terutama pada penerapan sistem pembukuan, administrasi keuangan pengelolaan sampah. Pencatatan dalam pembukuan yang dilakukan masih sangat sederhana dan perlu ditingkatkan dalam hal kualitas pengelolannya, terutama pada pencatatan baik untuk bank sampah maupun nasabahnya.

Kegiatan pengabdian ini diharapkan dapat memberikan luaran: 1 . Meningkatnya nilai asset mitra yang dapat diukur dari jumlah dan nilai aset-aset yang dimiliki oleh mitra yang digunakan untuk membuat handycraf berbahan sampah non organik. 2. Meningkatnya jumlah produk (diversifikasi) produk dari bahan sampah non organik. 3. Meningkatnya kualitas penanganan manajemen pengelolaan keuangan bank sampah.

\section{METODE PENGABDIAN}

Mengacu pada permasalahan pada mitra bank sampah, maka diperlukan metode pendekatan guna mendukung realisasi program pengabdian. Metode yang diterapkan dalam kegiatan ini, disesuaikan dengan tujuan yang telah ditentukan. Secara detail tahapan metode yang digunakan dalam pengabdian ini adalah sebagai berikut:

a. Penanganan sampah non organik

Dalam kegiatan pengabdian ini, masalah pertama yang menjadi tujuan untuk dilakukanya penyelesaian adalah masalah bagaimana menangani masalah sampah khususnya untuk jenis sampah 


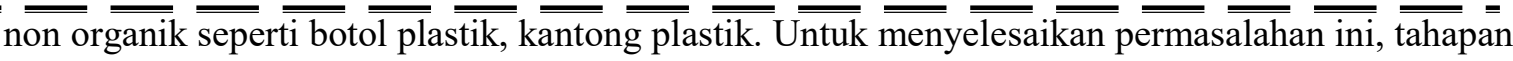
metode yang digunakan adalah:

1) Melakukan kegiatan studi banding pada para pengelola ke bank sampah lain yang sudah melakukan pengelolaan sampah dengan baik, khususnya untuk penanganan sampah non organik. Dalam kegiatan tersebut juga dilakukan diskusi bersama antara tim pengabdian, mitra pengabdian dan obyek yang dituju untuk dilakukannya kegiatan studi banding.

2) Memberikan bantuan peralatan dan perlengkapan (soldier, alat tembak dan bahan-bahan pembantu lainnya untuk pembuatan handycraf berbahan sampah non organik.

b. Penataan manajemen

Kegiatan penataan untuk manajemen dilakukan khususnya memberikan pengarahan dan pendampingan untuk pengelolaan pencatatan penerimaan sampah dari warga serta memberikan pengetahuan tentang bagaimana memasarkan produk yang dihasilnya dalam hal ini produk handycraf. Secara detail tahapan yang dilakukan untuk menyelesaikan masalah manajemen adalah:

1) Melakukan pendampingan untuk pengelolaan pembukuan sederhana. Dalam kegiatan ini tim pengabdi bersama mitra berdiskusi, dan tim pengadian memberikan masukan dan perbaikan atas model pembukuan yang selama ini dilakukan oleh mitra bank sampah.

2) Melakukan kegiatan penyuluhan masalah kegiatan memasarkan barang. Dalam kegiatan ini, tim pengabdian memberikan pengetahuan tentang bagaimana cara memasarkan produk yang telah dihasilkan (handycraf berbahan sampah non organik) ke masyarakat.

\section{HASIL DAN PEMBAHASAN}

Bank sampah mengajarkan masyarakat untuk memilah sampah, menumbuhkan kesadaran masyarakat mengolah sampah secara bijak agar dapat mengurangi sampah yang diangkut ke TPA. Selain itu warga yang menyerahkan sampah akan memperoleh tambahan penghasilan untuk kemandirian ekonomi warga dapat digunakan untuk usaha simpan pinjam seperti koperasi, dengan bunga rendah agar keuangan bank sampah dapat diputar dan dikembangkan, juga terwujudnya kesehatan lingkungan. Kegiatan dalam bank sampah di bank sampah mawar Joho Sukoharjo merupakan kegiatan yang banyak dilakukan oleh perempuan. Kelompok ini secara rutin melakukan kegiatan mulai dari penerimaan sampah, penimbangan sampai pemilahan.

Pembinaan warga perempuan telah menunjukkan kemampuan warga perempuan dalam menggerakkan komunitasnya untuk berperan aktif mengelola sampah di lingkungannya sekaligus melakukan kontrol sosial di komunitasnya. Dalam pelaksanaan edukasi terhadap warga dengan pengembangan bank sampah, harus terus dilakukan koordinasi secara intensif dengan para pengurus RT pada setiap kegiatan yang akan dilakukan agar pemberdayaan warga menjadi lebih maksimal dan kegiatan dapat dilakukan secara efektif, termasuk kegiatan-kegiatan di bank sampah Mawar Joho juga melibatkan pengurus RT terutama dalam hal sosialisasi kegitan bank sampah.

Hasil kegiatan pengabdian yang dilakukan di bank sampah Joho Kabupaten Sukoharjo secara rinci diuraikan sebagai berikut:

1. Pemanfaatan sampah non organik

Kegiatan ini dilakukan dengan tujuan memberikan pengetahuan tentang pemanfaatan sampah non organik seperti plastik bekas minyak, sabun serta botol berbahan plastik dimanfaatkan untuk menghasilkan produk handycraf. Kegiatan pelatihan dan pendampingan ini dilakukan pada bulan Februari sampai dengan bulan Mei 2020. Pada periode tersebut kegiatan yang dilakukan meliputi:

a. Melakukan studi banding

Kegiatan studi banding dilakukan pada bank sampah Ngadirojo Kabupaten Sukoharjo. Kegiatan studi banding menghasilkan wawasan bagi pengelola mengenai pemanfaaan sampah di bank sampah Ngadirojo, terutama pemanfaatan sampah non organik. Selain itu, 


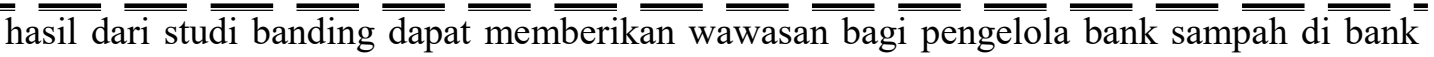
sampah Joho Sukoharjo mengenai model pengelolaan yang baik.

b. Pelatihan produk handycraf

Untuk menunjang kegiatan pelatihan, diberikan beberapa peralatan untuk membuat handycraf diantaranya adalah soldir, alat untuk mesin tembak dan alat untuk pemberi warna untuk handycraf (kompresor mini). Selain itu, juga diberikan bahan-bahan penunjang lainnya untuk menghasilkan handycraf. Kegiatan pelatihan yang dilakukan menghasilkan beberapa model handycraf seperti vas bunga, bunga dengan berbagai jenis bunga, dan berbagai jenis model bros.

2. Pengelolaan bank sampah

Kegiatan pendampingan dalam pengelolaan sampah yang diberikan oleh tim pengabdian diberikan kepada para pengelola bank sampah mawar di Joho Sukoharjo. Bentuk pendampingan yang diberikan terutama dalam hal model pencatatan setoran dari para anggota (nasabah bank sampah mawar) beserta menentukan harga dari jenis sampah yang disetorkan ke bank sampah. Kegiatan pendampingan ini menghasilkan model mencatatan yang dipakai untuk operasional penerimaan setoran sampah dengan memisahkan antara sampah organik dan sampah non organik dengan jenisjenis sampahnya.

\section{SIMPULAN}

Pengabdian ini dilakukan dengan mitra bank sampah. Kegiatan yang dilakukan dalam pelaksanaan pengabdian meliputi kegiatan untuk meningkatkan produktivitas bank sampah melalui pemanfaatan limbah sampah non organik dan peningkatan pengelolaan bank sampah. Kegiatan ini memberikan manfaat terutama bagi para pengelola bank sampah supaya pengelolaan bank sampah lebih produktif dan lebih baik. Cakupan kegiatan ini hanya dalam lingkup bank sampah saja sehingga penanganan bank sampah secara umum belum dapat dilakukan dengan maksimal. Oleh karena itu dalam kegiatan selanjutnya perlu bermitra dengan beberapa bank sampah yang lain dan tidak hanya pada aspek pengelolaan sampah non organik tetapi dapat dilakukan pada cara pemanfaatan dan pengelolaan sampah organik dan pengelolaan sampah organik menjadi pupuk kompos.

\section{SARAN}

Kegiatan hasil pengabdian ini diharapkan menjadi kegiatan yang berkelanjutan untuk masa yang akan datang pada kegiatan-kegiatan pengabdian lainnya. Masalah-masalah yang ada di mitra pengabdian diharapkan dapat diselesaikan secara menyeluruh melalui kegiatan pengabdian yang berkesinambungan sehingga kualitas pelaksanaan pengabdian dan hasil publikasi dari hasil pelaksanaan pengabdian akan lebih baik.

\section{UCAPAN TERIMA KASIH}

Penulis mengucapkan terima kasih kepada semua pihak yang mendukung demi kelancaran kegiatan pengabdian yaitu kepada Pengurus RT 02/RW09 Perumahan Joho, Joho Kabupaten Sukoharjo dan pengurus bank sampah mawar yang telah bersedia bermitra dengan tim pengabdian untuk mendukung pelaksanaan kegiatan pengabdian. Selain itu, penulis mengucapkan terima kasih kepada Yayasan pergururuan tinggi Slamet Riyadi Surakarta yang telah mendukung kegiatan pengabdian ini dengan memberikan support dana untuk pelaksanaan kegiatan. 


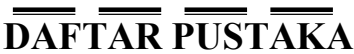

Aryenti, 2011. Peningkatan Peranserta Masyarakat Melalui Gerakan Menabung Pada Bank Sampah Di Kelurahan Babakan Surabaya, Kiaracondong Bandung. Pusat Litbang Permukiman. Bandung

Asmiyati, Agustaman, 2012, Bank Sampah. Buku Profil Bank Sampah Indonesia.

Djamaludin, Murniati Sri dan Wahyono Sri, 2008, Pengomposan Sampah, Skala Rumah Tangga, Edisi Kedua, November 2008, Penerbit Asdep Urusan Limbah Domestik dan Usaha Skala Kecil, Kementerian Negara Lingkungan Hidup, Jakarta.

Irdam, Ahmad, 2013, Bank Sampah: Sarana Pendidikan Lingkungan Hidup Untuk Masyarakat, Jurnal Lingkungan Hidup, ISSN 2089 5658, Jakarta.

Jumar, Fitriyah, N., dan Kalalinggie, R., 2014. Strategi Pengelolaan Sampah Rumah Tangga di Kelurahan Lok Bahu Kecamatan Sungai Kunjang Kota Samarinda. Journal Administrative Reform, 2(1):771-782

Republik Indonesia, Undang-Undang RI No. 18, 2008, Pengelolaan Sampah. Jakarta

Suyoto, Bagong, 2008. Rumah Tangga Peduli Lingkungan. Cetakan pertama. Prima Media, Jakarta 